\title{
A Supramolecular Triarm Star Polymer from a Homotritopic Tris(Crown Ether) Host and a Complementary Monotopic Paraquat-Terminated Polystyrene Guest by a Supramolecular Coupling Method
}

\author{
Feihe Huang, Devdatt S. Nagvekar, Carla Slebodnick, and Harry W. Gibson* \\ Department of Chemistry, Virginia Polytechnic Institute and State University, Blacksburg, Virginia 24061-0212
}

Supplemental Material (6 pages)

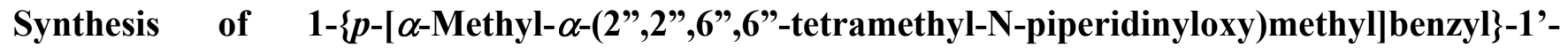
methyl-4,4'-bipyridinium Bis(hexafluorophosphate) (1)

A mixture of 1-methyl-4,4'-bipyridinium hexafluorophosphate ${ }^{\mathrm{S} 1}(632 \mathrm{mg}, 2.00 \mathrm{mmol}) \mathrm{N}-[p$ (chloromethyl)- $\alpha$-methylbenzyloxy]-2,2,6,6-tetramethylpiperidine ${ }^{\mathrm{S} 2}$ (650 $\mathrm{mg}, 2.10 \mathrm{mmol}$ ), and sodium iodide $(600 \mathrm{mg}, 4.00 \mathrm{mmol})$ in acetone $(100 \mathrm{~mL})$ were refluxed for 48 hours. The precipitate was filtered off, dissolved in $100 \mathrm{~mL}$ deionized water, and extracted with chloroform $(3 \times 20 \mathrm{~mL})$. Solid $\mathrm{NH}_{4} \mathrm{PF}_{6}$ was added into aqueous layer until no further precipitation was observed. The new precipitate was filtered off and recrystallized from deionized water three times to afford 1 as a white solid, $1.23 \mathrm{~g}$ (84\%), mp 201.8-202.9 ${ }^{\circ} \mathrm{C}$. The proton NMR spectrum of the product is shown in Figure S1. ${ }^{1} \mathrm{H}$ NMR $\left(400 \mathrm{MHz}, \mathrm{CD}_{3} \mathrm{COCD}_{3}, 22^{\circ} \mathrm{C}\right) \delta(\mathrm{ppm}): 9.57(2 \mathrm{H}, \mathrm{d}, J=5.8 \mathrm{~Hz}), 9.41(2 \mathrm{H}, \mathrm{d}, J=5.8 \mathrm{~Hz}), 8.91(2 \mathrm{H}, \mathrm{d}, J$ $=5.8 \mathrm{~Hz}), 8.86(2 \mathrm{H}, \mathrm{d}, J=5.8 \mathrm{~Hz}), 7.68(2 \mathrm{H}, \mathrm{d}, J=8.2 \mathrm{~Hz}), 7.53(2 \mathrm{H}, \mathrm{d}, J=5.8 \mathrm{~Hz}), 6.21(2 \mathrm{H}, \mathrm{s}), 4.93$ $(1 \mathrm{H}, \mathrm{q}, J=6.6 \mathrm{~Hz}), 4.78(3 \mathrm{H}, \mathrm{s}), 1.50(3 \mathrm{H}, \mathrm{d}, J=6.6 \mathrm{~Hz})$, and $0.68 \sim 1.64(18 \mathrm{H}, \mathrm{m})$. LRFABMS (NBA) $m / z 736.2[\mathrm{M}+\mathrm{H}]^{+}, 591.2\left[\mathrm{M}-\mathrm{PF}_{6}\right]^{+}, 446.1\left[\mathrm{M}-2 \mathrm{PF}_{6}\right]^{+}$; HRFABMS (NBA/PEG) $\mathrm{m} / z$ calcd for $[\mathrm{M}+$ $\mathrm{H}^{+} \quad \mathrm{C}_{29} \mathrm{H}_{40} \mathrm{~N}_{3} \mathrm{O}_{1} \mathrm{P}_{2} \mathrm{~F}_{12}, 736.2455$, found 736.2464 , error $1.2 \mathrm{ppm}$. Anal. calcd for $\mathrm{C}_{29} \mathrm{H}_{39} \mathrm{~N}_{3} \mathrm{O}_{1} \mathrm{P}_{2} \mathrm{~F}_{12} \bullet 0.5 \mathrm{H}_{2} \mathrm{O}: \mathrm{C}, 46.76 ; \mathrm{H}, 5.42 ; \mathrm{N}$, 5.64. Found: C, 46.58; H, 5.32; N, 5.67.

(S1) Winslow, L. N.; Rillema, D. P.; Welch, J. H.; Singh, P. Inorg. Chem. 1989, 28, 1596-1599.

(S2) Dao, J.; Benoit, D.; Hawker, C. J. J. Polym. Sci., Part A: Polym. Chem. 1998, 36, 2161-2167. 


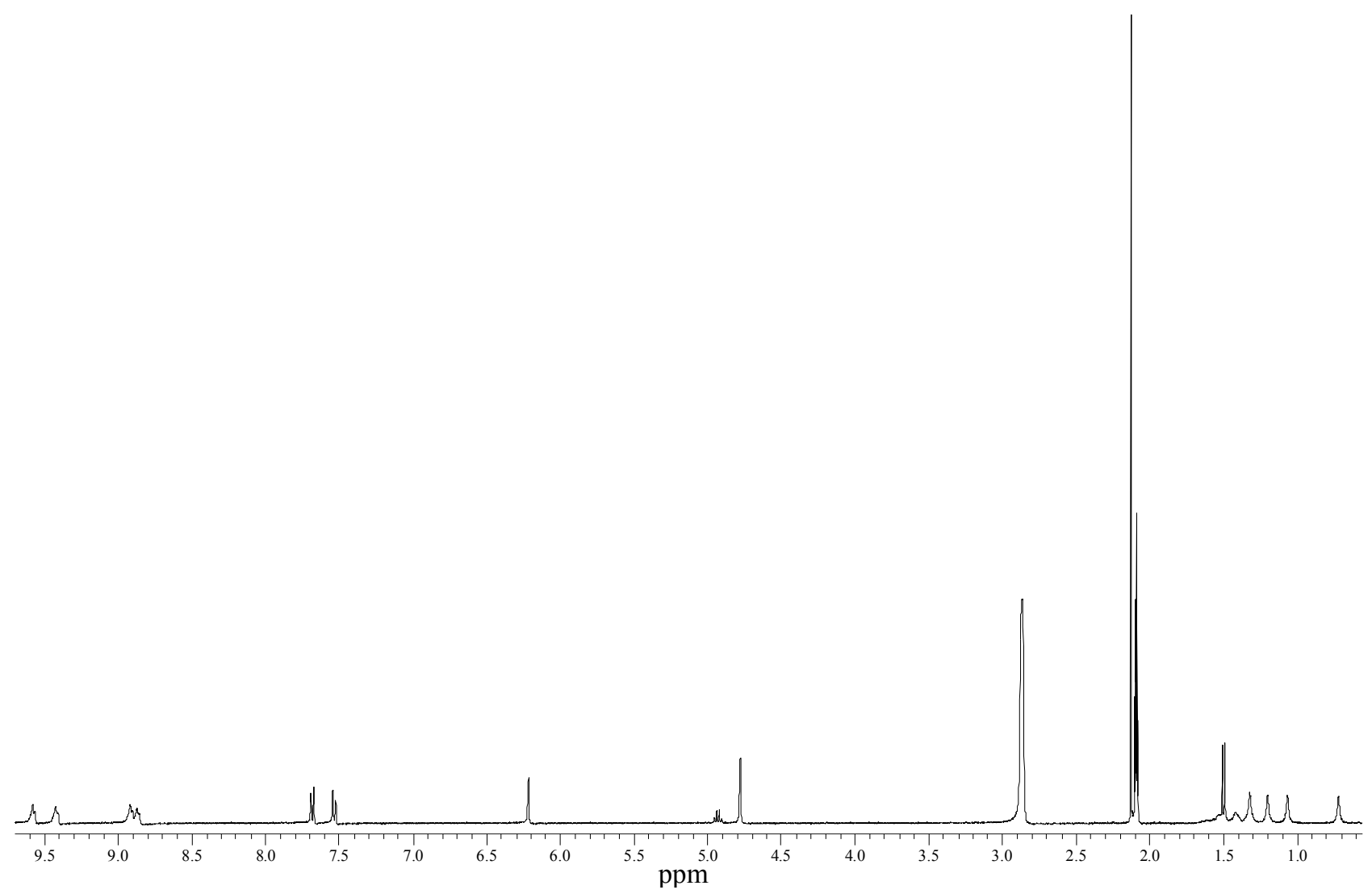

Figure S1. ${ }^{1} \mathrm{H}$ NMR Spectrum $\left(400 \mathrm{MHz}, \mathrm{CD}_{3} \mathrm{COCD}_{3}, 22^{\circ} \mathrm{C}\right)$ of $\mathbf{1}$.

Confirmation of the structure of 1 by X-ray analysis of a pseudorotaxane BPP34C10॰1

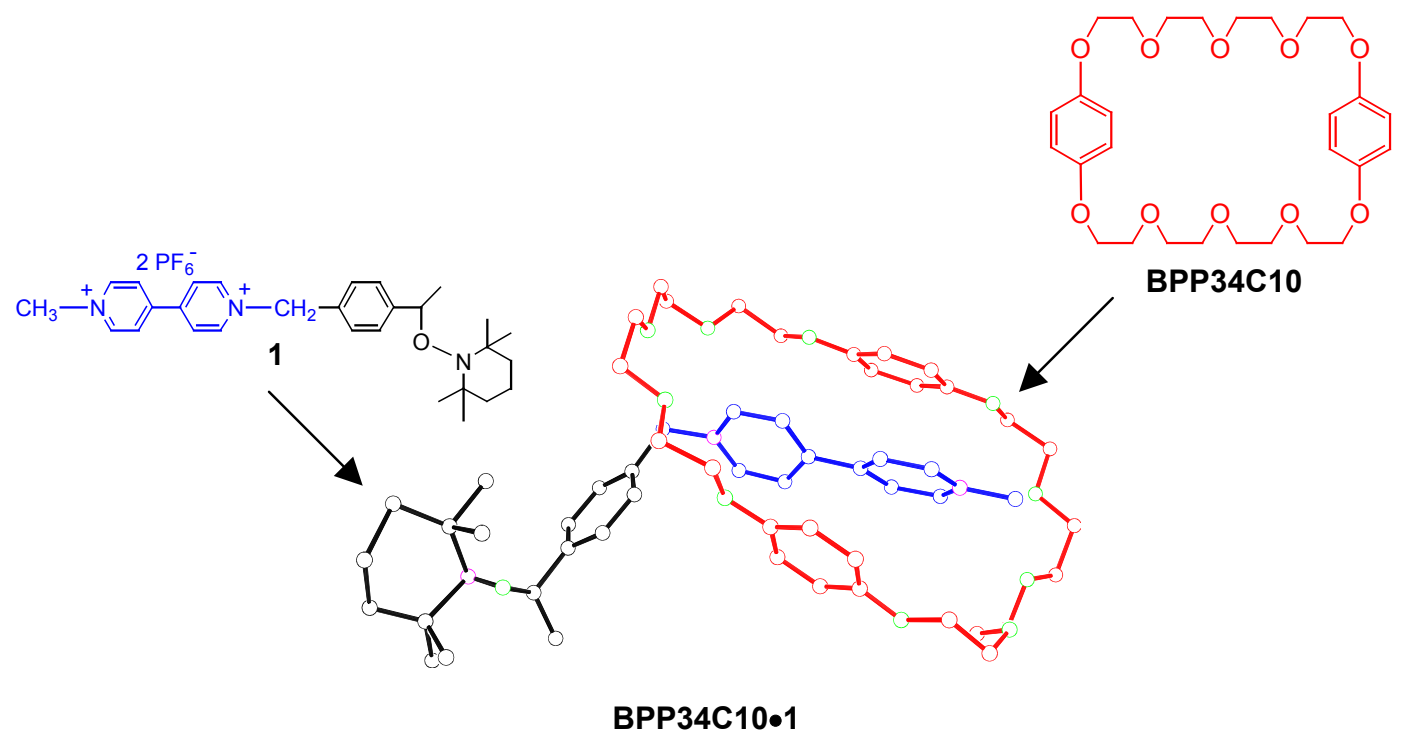


Red needles $\left(0.09 \times 0.12 \times 0.47 \mathrm{~mm}^{3}\right)$ were crystallized from acetone/pentane by vapor diffusion at room temperature. The chosen crystal was mounted on a nylon CryoLoop ${ }^{\mathrm{TM}}$ (Hampton Research) with Krytox ${ }^{\circledR}$ Oil (DuPont) and centered on the goniometer of an Oxford Diffraction Xcalibur2 ${ }^{\mathrm{TM}}$ diffractometer equipped with a Sapphire $2^{\mathrm{TM}}$ CCD detector. The data collection routine, unit cell refinement, and data processing were carried out with the program CrysAlis. ${ }^{\mathrm{S} 3}$ The unit cell parameters were consistent with the triclinic space group $\mathrm{P} \overline{1}$. The structure was solved by direct methods and refined using the SHELXTL NT program package. ${ }^{\mathrm{S}}$ The asymmetric unit of the structure comprises one crystallographically independent host:guest complex and a variety mostly evaporated and thus unidentified solvent. The final refinement model involved anisotropic displacement parameters for nonhydrogen atoms and a riding model for all hydrogen atoms. After locating the main residues, additional residual electron density that was presumably evaporated/disordered solvent could not be modeled successfully. Consequently, the SQUEEZE ${ }^{\mathrm{S} 5}$ subroutine of the program package PLATON ${ }^{\mathrm{S} 6}$ was used to identify potential solvent/void regions and subtract any electron density contribution in this region from the structure factors. A total of $660 \AA^{3}$ void space was identified ( $18.6 \%$ of total cell volume), but electron density totaling only $18.3 \mathrm{e}^{-}$was subtracted. Presumably the strong non-bonding interactions between the host and guest allowed the solvent to evaporate without the sample losing crystallinity. The TEMPO fragment of the guest molecule borders the void region and exhibits substantial disorder in the form of very large anisotropic displacement parameters and unreasonable metrical parameters. Attempts to model this disorder were unsuccessful. Presumably, the close proximity to the void region allows for substantial motion and/or multiple orientations of the TEMPO fragment. The program packages SHELXTL NT and PLATON were used to generate crystallographic tables. ${ }^{\mathrm{S}, \mathrm{S} 6}$ The program package SHELXTL NT was used for molecular graphics generation. ${ }^{\text {S4 }}$

(S3) CrysAlis v1.171, Oxford Diffraction: Wroclaw, Poland, 2004.

(S4) Sheldrick, G. M. SHELXTL NT ver. 6.12; Bruker Analytical X-ray Systems, Inc.: Madison, WI, 2001.

(S5) van der Sluis, P.; Spek, A. L. Acta Crystollgr., Sect. A: Found. Crystallogr. 1990, 46, 194-201.

(S6) Spek, A. L. J.Appl.Cryst. 2003, 36, 7-13.

\section{Synthesis of Paraquat-terminated Polystyrene (2)}

A stirred mixture of the initiator $1(0.184 \mathrm{~g}, 0.250 \mathrm{mmol})$ and styrene $(5.21 \mathrm{~g}, 50.0 \mathrm{mmol})$ under $\mathrm{N}_{2}$ was maintained at $125^{\circ} \mathrm{C}$ in an oil bath for $1 \mathrm{~h}$. The reaction mixture became viscous and the magnetic stirrer stopped. The reaction mixture was dissolved in chloroform and precipitated into methanol; the solid was reprecipitated several times and vacuum dried to afford 2 as a white solid (2.51 g, 47\%). ${ }^{1} \mathrm{H} \mathrm{NMR}\left(400 \mathrm{MHz}, \mathrm{CDCl}_{3}, 22{ }^{\circ} \mathrm{C}\right) \delta(\mathrm{ppm}): 8.66-8.80(4 \mathrm{H}, \mathrm{m}), 8.20-8.30(4 \mathrm{H}, \mathrm{m}), 5.65(2 \mathrm{H}$, $\mathrm{s})$, and $4.30(3 \mathrm{H}, \mathrm{s})$. GPC Results (polystyrene as the standard and 1-methyl-2-pyrrolidinone as the solvent): $M_{\mathrm{w}}=44.3 \mathrm{~kg} / \mathrm{mol}, M_{\mathrm{n}}=32.3 \mathrm{~kg} / \mathrm{mol}, \mathrm{PDI}=1.37 .{ }^{1} \mathrm{H}$ NMR end group analysis by referencing $\alpha$ - and $\beta$-pyridinium proton signals of the paraquat moiety (8.66-8.80 and 8.20-8.30 ppm) to the aromatic signals $(6.3-7.3 \mathrm{ppm})$ indicated $M_{\mathrm{n}}=35.0 \mathrm{~kg} / \mathrm{mol}$, including the paraquat and TEMPO end groups. 


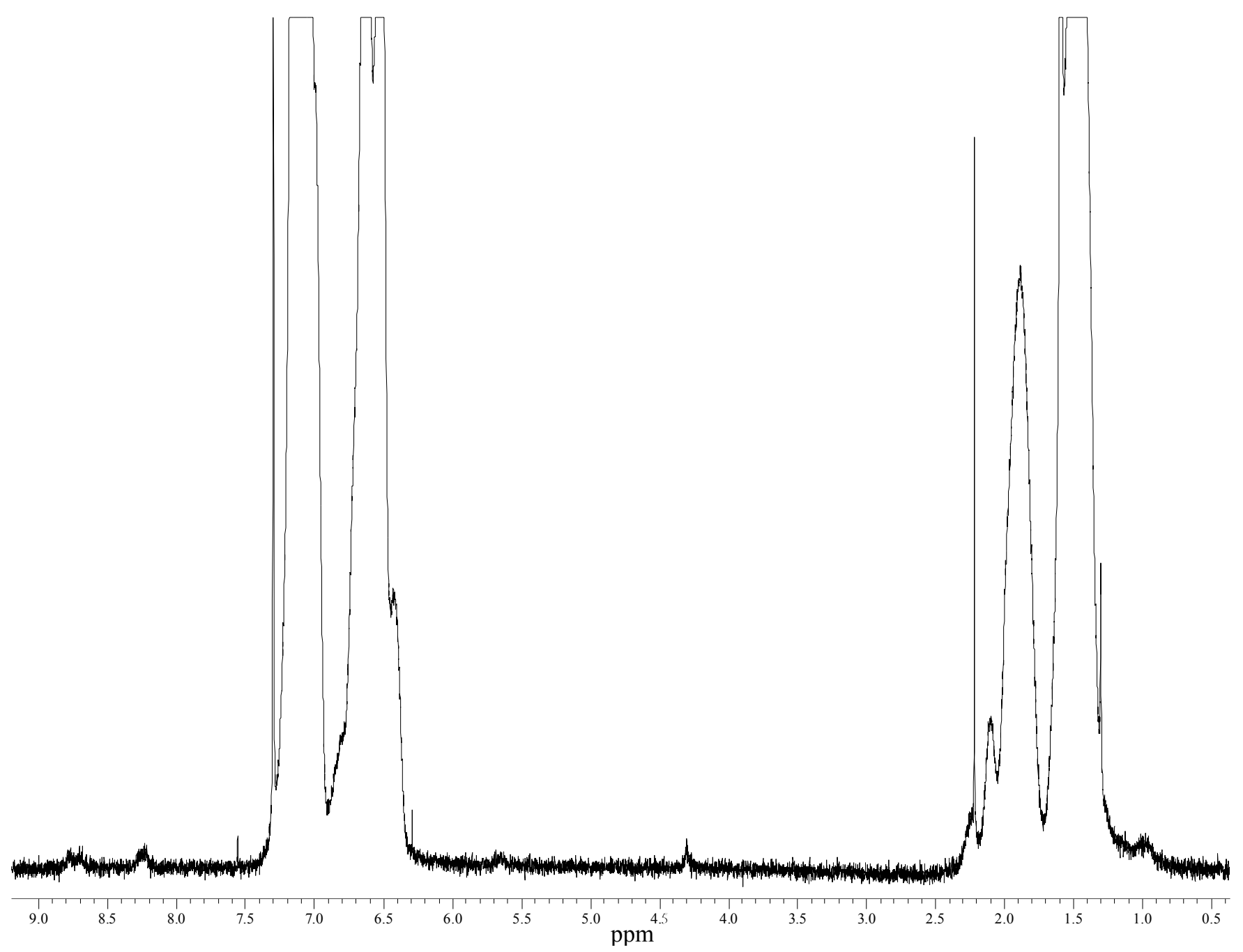

Figure S2. ${ }^{1} \mathrm{H}$ NMR Spectrum $\left(400 \mathrm{MHz}, \mathrm{CDCl}_{3}, 22{ }^{\circ} \mathrm{C}\right)$ of 2.

Synthesis of Bis(5-methylene-1,3-phenylene-1',3'-phenylene-32-crown-10) Terephthalate (7).

Terephthaloyl chloride $(1.01 \mathrm{~g}, 4.93 \mathrm{mmol})$ was added to a solution of 5-hydroxymethylene-1,3phenylene-1',3'-phenylene-32-crown-10 (4, $5.6415 \mathrm{~g}, 9.963 \mathrm{mmol})$ in anhydrous THF (125 mL) containing pyridine $(0.900 \mathrm{~mL}, 11.1 \mathrm{mmol})$ and the mixture was refluxed for $48 \mathrm{~h}$. After cooling, the precipitated pyridinium hydrochloride salt was filtered and the organic layer was washed with water and $10 \%$ hydrochloric acid $(25 \mathrm{ml})$ solution. The organic layer was dried over anhydrous sodium sulfate and evaporated to dryness. The crude product was purified by silica gel column chromatography with ethyl acetate as the eluent. Evaporation of the solvent gave $7(5.30 \mathrm{~g}, 85 \%)$ as an oil. Recrystallization from 2:8 dichloromethane / hexane gave a white solid, mp 75.7-77.9 ${ }^{\circ} \mathrm{C}$. IR (neat): $2924(-\mathrm{CH}), 1722(\mathrm{C}=\mathrm{O})$, 1596, 1489, $1456(\mathrm{C}=\mathrm{C})$ and $1264[\mathrm{C}-\mathrm{C}(=\mathrm{O})-\mathrm{C}]$ and $1124(\mathrm{C}-\mathrm{O}-\mathrm{C}) .{ }^{1} \mathrm{H} \mathrm{NMR}\left(400 \mathrm{MHz}, \mathrm{CDCl}_{3}, 22^{\circ} \mathrm{C}\right)$ $\delta(\mathrm{ppm}): 8.11(4 \mathrm{H}, \mathrm{s}), 7.11(2 \mathrm{H}, \mathrm{m}, J=8.5 \mathrm{~Hz}), 6.57(4 \mathrm{H}, \mathrm{d}, J=2.2 \mathrm{~Hz}), 6.48(8 \mathrm{H}, \mathrm{m}), 5.26(4 \mathrm{H}, \mathrm{s}), 4.07$ $(16 \mathrm{H}, \mathrm{m}), 3.83(16 \mathrm{H}, \mathrm{m})$, and $3.69(32 \mathrm{H}, \mathrm{m}) .{ }^{13} \mathrm{C} \mathrm{NMR}\left(400 \mathrm{MHz}, \mathrm{CDCl}_{3}, 22{ }^{\circ} \mathrm{C}\right) \delta(\mathrm{ppm}): 66.945$, 67.453, 67.582, 69.592, 69.645, 70.829, 70.851, 101.164, 101.612, 106.907, 107.028, 129.672, 129.740, 133.882, 137.675, 159.916, 160.075, 165.492 (18 peaks; theoretical 19). LRFABMS (NBA) $m / z 1260.7$ 
$[\mathrm{M}]^{+}$and $1097.5\left[\mathrm{M}-\mathrm{C}_{10} \mathrm{H}_{11} \mathrm{O}_{2}\right]^{+}$; HRFABMS (NBA/PEG) $\mathrm{m} / z$ calcd for $[\mathrm{M}]^{+} \mathrm{C}_{66} \mathrm{H}_{86} \mathrm{O}_{24}, 1262.5509$, found 1262.5461, error 3.8 ppm. Anal. calcd for $\mathrm{C}_{66} \mathrm{H}_{86} \mathrm{O}_{24}: \mathrm{C}, 62.73 ; \mathrm{H}, 6.86$. Found: $\mathrm{C}, 62.65 ; \mathrm{H}, 6.86$.

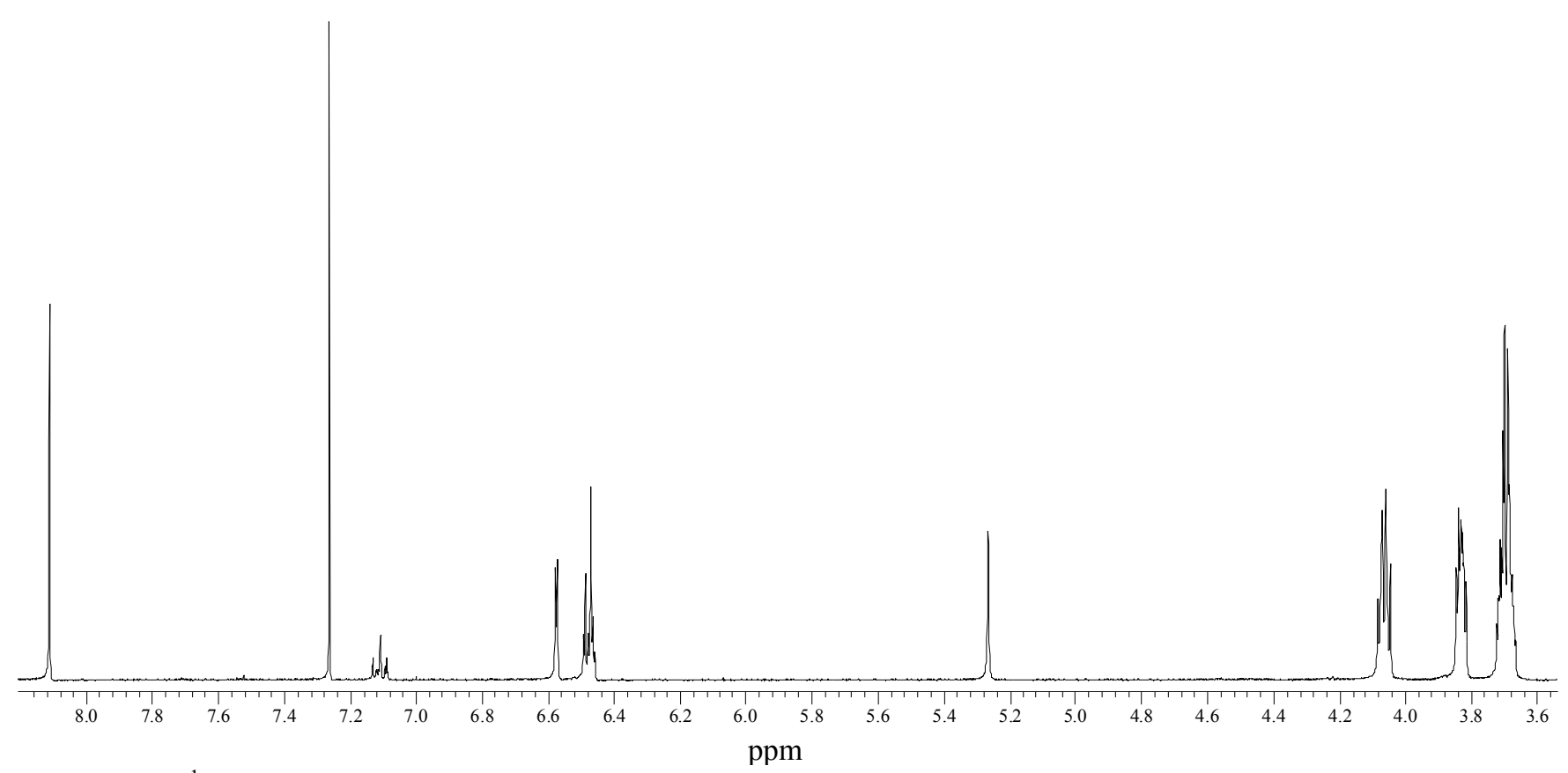

Figure S3. ${ }^{1} \mathrm{H}$ NMR Spectrum $\left(400 \mathrm{MHz}, \mathrm{CDCl}_{3}, 22^{\circ} \mathrm{C}\right)$ of 7 .

Synthesis of 1,3,5-Benzenetricarbonyl Tris(5-methylene-1,3-phenylene-1',3'-phenylene-32-crown10 (3).

1,3,5-Benzenetricarbonyl trichloride $(0.181 \mathrm{~g}, 0.683 \mathrm{mmol})$ was added to a solution of 5 hydroxymethylene-1,3-phenylene-1',3'-phenylene-32-crown-10 (4, $1.17 \mathrm{~g}, 2.05 \mathrm{mmol})$ in anhydrous THF $(75 \mathrm{~mL})$ containing pyridine $(0.17 \mathrm{ml}, 2.10 \mathrm{mmol})$. After refluxing for $72 \mathrm{~h}$, the salt was filtered and the organic layer was washed with water and $10 \%$ hydrochloric acid $(25 \mathrm{~mL})$. The organic layer was dried over anhydrous sodium sulfate and evaporated to dryness. The crude product was purified by silica gel column chromatography by elution with ethyl acetate followed by absolute ethanol. Evaporation of the solvent gave 3 (1.12 g, 88.4\%), an oil. IR (neat) $2924(-\mathrm{CH}), 1722(\mathrm{C}=\mathrm{O}), 1602,1489(\mathrm{C}=\mathrm{C}) 1237$ [C-C $(=\mathrm{O})-\mathrm{O}]$, and $1131(\mathrm{C}-\mathrm{O}-\mathrm{C}) .{ }^{1} \mathrm{H}$ NMR $\left(400 \mathrm{MHz}, \mathrm{CDCl}_{3}, 22{ }^{\circ} \mathrm{C}\right) \delta(\mathrm{ppm}): 8.86(3 \mathrm{H}, \mathrm{s}), 7.10(3 \mathrm{H}$, $\mathrm{m}), 6.57(6 \mathrm{H}, \mathrm{d}, J=2.2 \mathrm{~Hz}), 6.47(12 \mathrm{H}, \mathrm{m}), 5.29(6 \mathrm{H}, \mathrm{s}), 4.06(24 \mathrm{H}, \mathrm{m}), 3.82(24 \mathrm{H}, \mathrm{m})$, and $3.69(48 \mathrm{H}$, m). ${ }^{13} \mathrm{C}$ NMR $\left(400 \mathrm{MHz}, \mathrm{CDCl}_{3}, 22{ }^{\circ} \mathrm{C}\right) \delta(\mathrm{ppm}): 67.156,67.452,67.566,69.576,69.645,70.813$, $70.851,101.353,101.611,107.035,129.739,131.165,134.852,137.538,159.908,160.067$, and 164.634 (17 peaks; theoretical 19). LRFABMS (NBA) $m / z 2028.5[\mathrm{M}+\mathrm{NaI}]^{+}, 1893.7[\mathrm{M}+\mathrm{K}]^{+}$, and $1877.6[\mathrm{M}$ $+\mathrm{Na}^{+}$; HRFABMS (NBA/PEG) $\mathrm{m} / z$ calcd for $[\mathrm{M}+\mathrm{Na}]^{+} \mathrm{C}_{96} \mathrm{H}_{126} \mathrm{O}_{36} \mathrm{Na}, 1877.7927$, found 1877.7974, error $2.5 \mathrm{ppm}$. 


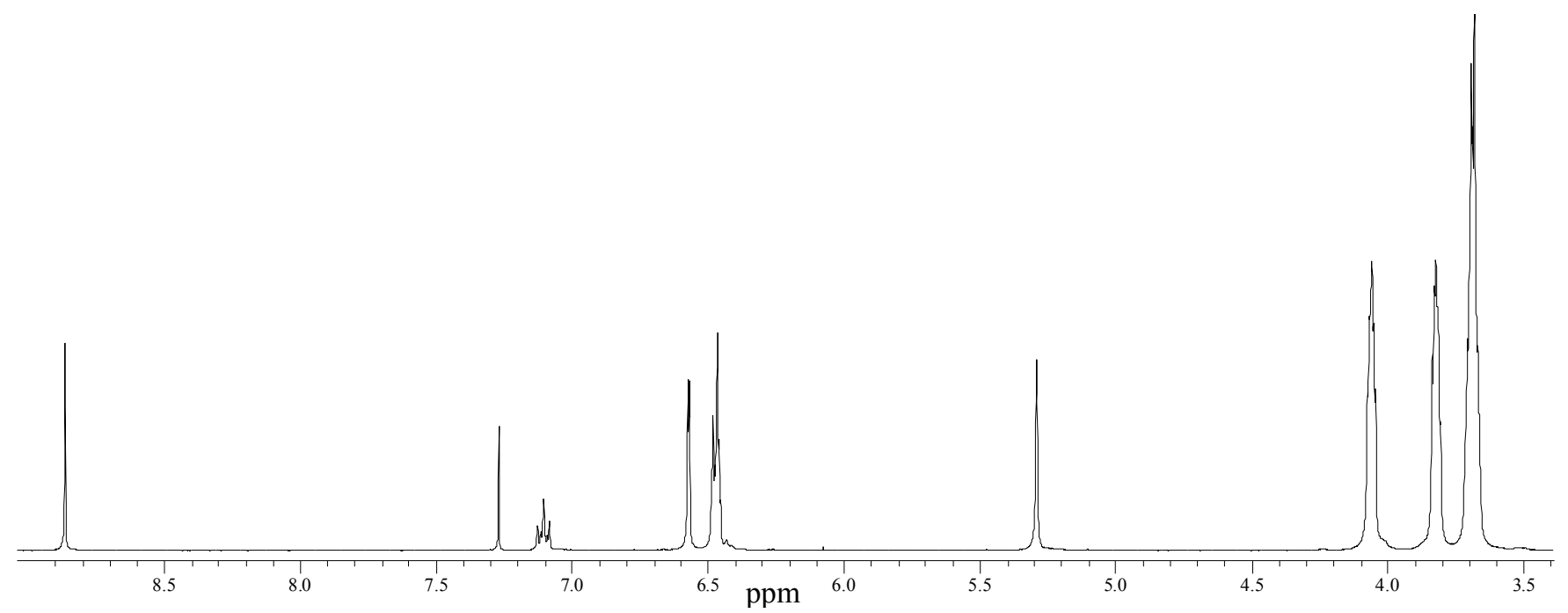

Figure S4. ${ }^{1} \mathrm{H}$ NMR Spectrum $\left(400 \mathrm{MHz}, \mathrm{CDCl}_{3}, 22^{\circ} \mathrm{C}\right)$ of 3. 